\title{
QAR : A Reading Strategy To Enhance Non-English Department Students' Reading Skill
}

\author{
TRI WAHYUNI, NURLAILALATULAQROMI, \\ DAN TIARA RETNO HARYANI
}

Program Studi Pendidikan Bahasa Inggris Fakultas Keguruan dan Ilmu Pendidikan Universitas Islam Lamongan

\begin{abstract}
Abstrak:
Question Answer Relationship (QAR) strategy is a teaching strategy in teaching reading comprehension. By applying the strategy, teacher can assist the students to comprehend a reading text easier though they have a limit vocabulary. This strategy allows students to comprehend the text by relating the questions and the answers that can be classified into two big categories, "in the text" and "in my head". At the end of the teaching learning process, students are supposed to be creative in comprehending a text using the QAR strategy. By implementing the strategy, the students are expected to extend the reading materials and continue to read more written materials
\end{abstract}

Kata kunci: Question Answer Relationship (QAR), Reading Skill

\section{Introduction}

Reading is a complex activity which does not only involve pronunciation but also visual, psycholinguistics, and intellectual activities. Reading as an intellectual activity involves words recognition, literal understanding, interpretation, critical reading, and creative comprehension. Recognizing the words can be done by looking up the words in the dictionary, Crawly and Mountain (in Par, 2011). In order to enhance the students' study skill, the integration of academic content and English language is first developed (Martinez, 2002:79); therefore, reading is a primary skill to teach. Furthermore, in tertiary level of education, Non-English department students learn English differently from English department students. The non-English department students learn English for academic purpose (EAP), while English department students learn general English. As a compulsory course, EAP is taught in the beginning of the study year to make the students equip with a study skill that is considered important to support their study in the following years (Robbinson, 1991:100 and Sulistyo, 2008:2).

Reading is a multifaceted activity. According to Braunger and Lewis (2001), reading means more than just understanding meaning stated implicitly and explicitly. They claim that reading is a complex, interactive process, using basic skills, and advanced strategies to 
make meaning. Meanwhile the teaching of English in tertiary level, especially for non-English department students, is aimed at providing the students to comprehend textbooks and other references written in English. Regarding to those concepts, reading is emphasized as the basis of classroom activities in teaching and learning process of nonEnglish department students.

Related to the teaching of English for non-English department in university, a lot of research shows that the teaching and learning process is not managed well. This condition has been taken place for almost thirty years (Sulistyo, 2008:2). Moreover, the problem arises when students try to understand English texts. Hamra (1996, in Hamra and Satriana, 2010:27) claims that in general, students of non-English department find it difficult to comprehend reading materials in English as foreign language. As a result, they do not enjoy reading English texts. In addition, the phenomenon also happens in Indonesia. The reading skill of Indonesian students to read English texts was very low because the teaching technique use seems monotonous.

By understanding the characteristics and identifying the problems of nonEnglish department students as stated previously, a suitable teaching technique is required to solve the problem. The technique should guarantee the effective teaching which makes the students learn (Mukminatien, 2011:214). Considering probem, the QAR strategy is presented in this study. It is intended to give an idea which might be applied in non-English department classes to make the students read actively.

\section{Description of Qar Strategy}

An important issue to be observed in this study is the reading strategy in reading comprehension instruction, i.e. Question Answer Relationship (QAR) strategy. QAR strategy shows the readers to explore the text from the information in the text itself (bottom up approach) and from the readers' experiential background knowledge (top down approach) to construct the meaning of the text.

QAR strategy can be an alternative to help the students to focus on analyzing reading texts. Raphael and Pearson (1982) have devised the QAR strategy as a way for students to understand that the answer to a question is directly related to the type of question that is asked. QAR strategy helps students in differentiating among questions on the basis of where the answer can be found: either "in the book" or "in my head". If answers are "in the book" the questions will be a literal type because the answers are "right there" in the text. If the questions are "in my head", inferential questions have been posed and readers must use their own background knowledge to compose that require information which is not provided in the text.

The two categories of questions, in the book and in my head, can be further delineated into four categories. For questions that can be found "in the book", students will either find them 
"right there" in one place in the text, or they will have to "think and search", also called "search and find". For these types of questions, students will need to search at several places in the text to find the answer. Questions from the "in my head" category are going to be "author and you" questions, where the student will need to use their own background knowledge and experiences in addition to the textual information to answer the question. They might also be classified as "on my own" questions, where the student will rely solely on background experiences and knowledge to supply the answer (Frank, Grossi, \& Stanfield, 2006)It is described in Table 1.

\begin{tabular}{|c|c|}
\hline In the text & In my head \\
\hline $\begin{array}{l}\text { Right There } \\
\text { The answer is in the } \\
\text { text and is usually easy } \\
\text { to find. The words used } \\
\text { in the question and the } \\
\text { words used for the } \\
\text { answer can usually be } \\
\text { found in the same } \\
\text { sentences }\end{array}$ & $\begin{array}{l}\text { Author and You } \\
\text { The answer is not } \\
\text { explicitly stated in the } \\
\text { text. The students need to } \\
\text { think about what they } \\
\text { already know, what the } \\
\text { author tells them in the } \\
\text { text, and how it fits } \\
\text { together. }\end{array}$ \\
\hline $\begin{array}{l}\text { Think and search } \\
\text { The answer is in the } \\
\text { text, but the words } \\
\text { used in the question } \\
\text { and those used for the } \\
\text { answer are not in the } \\
\text { same sentences. } \\
\text { Students need to think } \\
\text { about different parts of } \\
\text { the text and how ideas } \\
\text { can be put together } \\
\text { before answering the } \\
\text { question. }\end{array}$ & $\begin{array}{l}\text { On my own } \\
\text { The answer is not text- } \\
\text { based. Students may be } \\
\text { able to answer the } \\
\text { question without reading } \\
\text { the selection by using } \\
\text { their own experiences and } \\
\text { background knowledge. }\end{array}$ \\
\hline
\end{tabular}

\section{Table 1 : The QAR in Charts}

\section{Purpose For Using Qar Strategy}

The purpose of the QAR strategy is to improve student reading comprehensions by having them think creatively and working cooperatively to think about the selected text they are reading in order to ask questions and know where to find the answers.

\section{How To Use Qar Strategy}

Here are the steps of using QAR Strategy,

\section{(a) Explain the two broad categories of} questions (and the four subcategories) to students as an introduction to the QAR strategy.

The levels and types of comprehension questions are categorized into two big groups; those are in the text and in my head (Raphael, 1986). It means that actually the readers can find answers of certain questions in the text and in my head.

\section{Type 1: In the Text}

In this type, the answers are right there in the text. The answers can be found in the text explicitly. These types of questions are literal. There are "Right There" and "Think and Search". In the right there type, the answer is in one sentence of the text; the question and answer usually have the same wording. Answers usually are one-word or shortphrase responses. There is usually only one right answer to Right There questions.

Some examples of phrases used for Right There questions are who is....?, where is...?, what is...?, when is...?, how many...?, and when $\operatorname{did} . . . ?$

In the think and search type, the answer is found in several parts of the text. The question and answer have 
different wordings. Answers are usually short answers.

Some examples of phrases used for Think and Search questions are for what reason...?, how did...?, why was...?, and what caused...?

\section{Type 2: In My Head}

In this type, students must use their prior knowledge to answer these types of questions. There are "Author and Me" and "On My Own". In the type of Author and $\mathrm{Me}$, the answer to the question comes from both clues in the text and students' prior knowledge. Students must synthesize the text to fully understand the question.

Some examples of phrases used for author and me questions are would you...?, which character...?, did you agree with...?, what did you think of...?

In the type of On My Own, the answer comes entirely from students' prior knowledge. These questions require inferential and evaluative thinking. The answers do not require information from the text but do require that students make some type of judgment about or elate to the topic of the text.

Some examples of phrases used for On My Own questions are do you know...?, have you ever...?, would you ever...?

\section{(b) The teacher models the QAR process} by using a short reading passage

In this step, the teacher read the story and questions to the students. Then identify which QAR are indicated through the questions given. The teacher need to practice in identifying the QAR's with the class. Finally, the teacher and student answer and discuss the questions.

\section{(c) The teacher should gradually increase the length and complexity of the texts used with QAR}

The students continue to use QAR throughout the year, across the curriculum in science, social studies, health, etc.

\section{Teaching Procedures Of Qar Strategy}

QAR is a questioning strategy that emphasizes on the relationship which exists between the question, the text, and the background of the reader. In this strategy, students are taught to use four question/answer relationships (QAR's) to find the information they need to answer the question. The general teaching procedures of QAR strategy which is adopted from Raphael (1982) stated that firstly, the teacher introduces QAR and explains the four types of QAR.

Secondly, the teacher models the QAR process by using a short reading passage. In this case, the teacher read the story and questions to the students. Then, the students identify which QAR's are evidenced through the questions given. The teacher practices identifying the QAR's with the class. Finally, the teacher and student answer and discuss the questions.

After that, the teacher provides independent practice. The teacher should gradually increase the length and 
complexity of the texts used with QAR. Finally, the students continue to use QAR throughout the year, across the curriculum in science, social studies, health, etc. The Table 2 shows us how the teaching-learning activities that can be applied in the classroom.

\begin{tabular}{|l|l|l|}
\hline $\begin{array}{c}\text { Scenario } \\
\text { activities } \\
\text { stage }\end{array}$ & Teacher activities & Students' activities \\
\hline $\begin{array}{l}\text { Pre- } \\
\text { Reading } \\
\text { Activities }\end{array}$ & $\begin{array}{l}\text { 1. Leading students } \\
\text { to the topic by } \\
\text { giving and/or } \\
\text { showing a picture } \\
\text { 2. Introducing the } \\
\text { topic and } \\
\text { assigning } \\
\text { students to } \\
\text { predict the words } \\
\text { used in the text } \\
\text { 3. Conveying the } \\
\text { objective } \\
\text { learning, the four } \\
\text { categories of QAR } \\
\text { strategy }\end{array}$ & $\begin{array}{l}\text { 1. Paying attention to } \\
\text { the picture shown } \\
\text { the topic and } \\
\text { predicting the word } \\
\text { used in the text } \\
\text { the instructional } \\
\text { objectives stated by } \\
\text { teacher }\end{array}$ \\
\hline \multicolumn{2}{|c|}{} \\
\hline
\end{tabular}

\begin{tabular}{|c|c|c|}
\hline $\begin{array}{c}\text { Scenario } \\
\text { activities } \\
\text { stage }\end{array}$ & Teacher activities & Students' activities \\
\hline $\begin{array}{l}\text { Whilst } \\
\text { Reading } \\
\text { Activities }\end{array}$ & 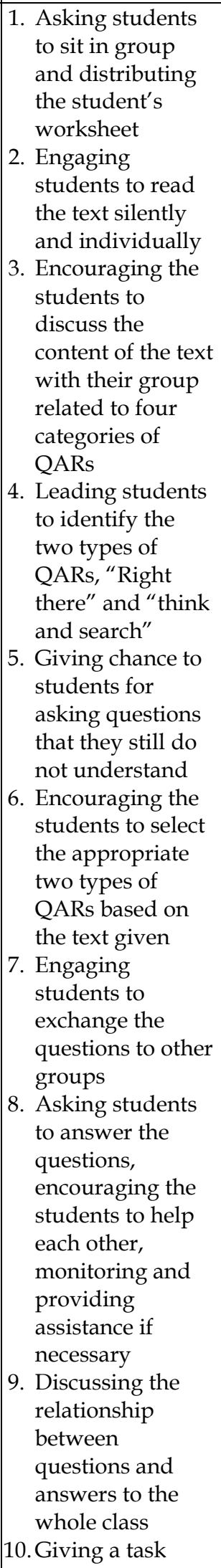 & $\begin{array}{l}\text { 1. Forming and sitting } \\
\text { in their group and } \\
\text { receiving } \\
\text { worksheet } \\
\text { 2. Paying attention to } \\
\text { the text being read } \\
\text { 3. Discussing the } \\
\text { content of the text } \\
\text { with their group } \\
\text { 4. Paying teacher's } \\
\text { instruction, } \\
\text { everyone thinking } \\
\text { the answer and } \\
\text { answer the } \\
\text { teacher's question } \\
\text { 5. Raising the } \\
\text { questions if they } \\
\text { don't understand } \\
\text { the text } \\
\text { 6. Selecting 'in the } \\
\text { book' questions } \\
\text { based on the text } \\
\text { given to the } \\
\text { appropriate } \\
\text { brackets provided } \\
\text { 7. Exchanging the } \\
\text { questions and } \\
\text { answering the } \\
\text { questions, working } \\
\text { and helping each } \\
\text { other } \\
\text { 8. Answering the } \\
\text { questions and } \\
\text { helping each other } \\
\text { 9. Giving respond to } \\
\text { the whole class' } \\
\text { discussion } \\
\text { 10. Receiving a task }\end{array}$ \\
\hline $\begin{array}{l}\text { Post } \\
\text { Reading }\end{array}$ & $\begin{array}{l}\text { 1. Collecting the } \\
\text { task }\end{array}$ & $\begin{array}{l}\text { 1. Submitting the task } \\
\text { 2. Giving feedback }\end{array}$ \\
\hline
\end{tabular}




\begin{tabular}{|c|l|l|}
\hline $\begin{array}{c}\text { Scenario } \\
\text { activities } \\
\text { stage }\end{array}$ & Teacher activities & Students' activities \\
\hline Activities & $\begin{array}{l}\text { 2. Asking the } \\
\text { students to give } \\
\text { feedback as } \\
\text { reflection }\end{array}$ & \\
\hline
\end{tabular}

Table 2. Teaching-Learning Activities

\section{QAR Chart Model}

This model is using an expository text because it is going to be taught in nonEnglish department (IT students). The reading test is entitled "Computer Viruses". Some of the questions can be classified into this table.

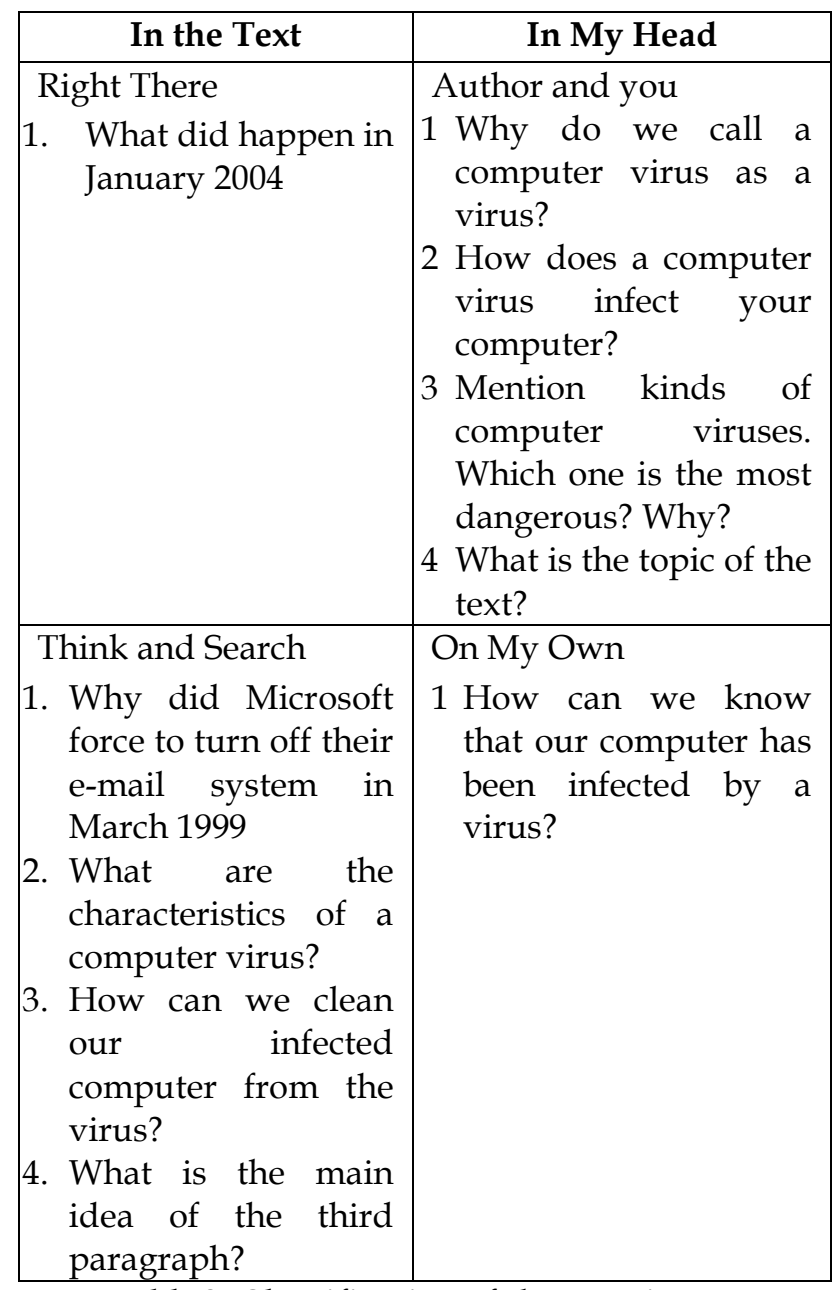

Table 3. Classification of the questions

\section{Conclusion}

In teaching reading comprehension for non-English department students, the lecturer should select a technique that encourages the students to actively read the texts to make the learning process run well. QAR Strategy has beneficial impacts towards the learning process in comprehending written text. The technique allows the students to extend the reading materials and continue the students to read more written materials.

\section{References}

Branger, J., \& Lewis, J. 2001. Building a Knowledge Base in Reading. Newark:IRA.

Conner, Jennifer. 2006. Instructional Reading Strategy: KWL (Know, Want to Learn, Learned). Retrieved February, 16, 2011, from http:/ / www.indiana.edu/ 1517/ KWL.htm

Hamra, Arifudin and Satriana, Eny. 2010. Developing A Model of Teaching Reading Comprehnsion for EFL Students. TEFLIN journal, 21(1): 27-40.

Martinez, Illiana A. 2002. Developing Genre Awareness in NonnativeEnglish-Speaking Writers of Experimental Research Articles: A Collaboratives Approach. In Crandall, JoAnn and Kaufman, Dorit (Eds.), Content-Based Instruction in Higher Education Setting (pp. 79-91). Virginia: TESOL Inc.

Mukminatien, Nur. 2011. Does our Teaching Cause Learning? A Reflection on our Teaching and 
Insights into Factors Affecting Language Learning. In Cahyono, Bambang Y. and Mukminatien, Nur (Eds.), Techniques and Strategy to Enhance English Language Learning. Malang: UM Press.

Par, L. 2011. Improving Students' Reading Comprehension of Expository Texts Through The Answer-Question Relationship Strategy. Unpublished Thesis: State University of Malang.

Raphael, T. E. \& Pearson P.D. 1982. The Effect of Metacognitive Awareness Training on Children' QuestionAnswering Behaviour. University of Illinois

Raphael, T. E. 1986. Teaching Question Answer Relationships, Revisited. The Reading Teacher (39) 6, 516522.

Robinson, Pauline C. 1991. ESP Today: A Practitioner's Guide. Hertfortshire: Prentice Hall International (UK).

Sasson, Dorit. 2008. Use K-W-L Technique in Reading Lessons. Strategic Thought Process for Engaging Students Before They Read. Retrieved February, 16, 2011, from http://www.suite101.com/conte nt/strategic-lesson-planning-forteaching-reading-a60272.

Sulistyo, Gunadi Harry. 2008. Pengembangan Tes Kemampuan Memahami Teks Akademik Berbahasa Inggris. Dissertation synopsis. Jakarta: Universitas Negeri Jakarta.
Vacca, Richard T. and Vacca, Jo Anne. 1999. Content Area Reading. Literacy and Learning across the Curriculum. Hoboken: AddisonWesley Educational Publisher.

Wuryanto, Agus. KWL Method. Retrieved February, 16, 2011, from http://pusatbahasaalazhar.word press.com/persembahan-buatguru/five-possible-methods-inteaching-reading/ 
